\title{
Physico-chemical Quality and Efficiency Study of Textile and Garments Effluent
}

\author{
BIDDUT CHANDRA SARKER ${ }^{1 *}$, MD. ABDUL BATEN ${ }^{1}$, MD. EKRAM UL HAQUE$^{2}$, \\ AHMED HOSSAIN ${ }^{3}$, MD. ZAHEDUL HASAN ${ }^{1}$ and SHIKHA SARKER ${ }^{4}$ \\ 1Department of Environmental Science, Bangladesh Agricultural University, \\ Mymensingh-2202, Bangladesh. \\ ${ }^{2}$ Soil Science Division, Bangladesh Institute of Nuclear Agriculture (BINA), \\ Mymensingh-2202, Bangladesh. \\ ${ }^{3}$ Department of Biotechnology, Bangladesh Agricultural University, Mymensingh-2202, Bangladesh. \\ ${ }^{4}$ Department of Textile Engineering, City University, Dhaka-1216, Bangladesh. \\ *Corresponding author E-mail: biddutsarker.bau@gmail.com
}

http://dx.doi.org/10.13005/ojc/320131

(Received: January 02, 2016; Accepted: February 13, 2016)

ABSTRACT

The objective of this study was to ascertain textile and garments effluents' quality parameters and suitability for irrigation and aquaculture. Concentration of different parameters i.e. $\mathrm{pH}$, temperature, color, odor, electrical conductivity (EC), dissolved oxygen (DO), total dissolved solids (TDS) and concentration of ionic constituents viz. $\mathrm{Na}^{+}, \mathrm{K}^{+}, \mathrm{Ca}^{2+}$ and $\mathrm{PO}_{4}^{2-}$ of effluents were investigated in Bhaluka industrial area of Mymensingh, Bangladesh during August to November, 2013. Study revealed that there were distinct variations in values of different parameters. Among the samples, $\mathrm{pH}$ values ranged from 7.5 to 9.8 indicating alkalinity of water. Temperature $\left(26.8-30.2^{\circ} \mathrm{C}\right)$ was found within permissible expelling limits. Observed color and odor of the effluents indicated poor quality to use for irrigation and aquaculture purposes. EC value (94.87- $\left.365.58 \mu \mathrm{Scm}^{-1}\right)$ indicated low salinity level of the effluents. DO was within the range of 0.30 to $1.3 \mathrm{mg} / \mathrm{L}$ indicating aquatic life was under stress. Considering TDS (53.68 to $267.05 \mathrm{mg} / \mathrm{L})$, all the samples were rated as fresh water $(<1000$ $\mathrm{mg} / \mathrm{L})$. Ratios of mean concentrations to background values were ranked in this sequence: $\mathrm{Na}^{+}>$ $\mathrm{K}^{+}>\mathrm{PO}_{4}{ }^{3-}>\mathrm{Ca}_{2}{ }^{+}$. Overall study revealed that due to imbalance in values of different water quality parameters all of the samples were unsuitable for irrigation and aquaculture.

Key words: Effluent, Water, Physico-chemical Quality, Irrigation;

Aquaculture, Suitability, Textile and Garments.

\section{INTRODUCTION}

Rapid industrialization and direct discharge of industrial effluents as wastewater affects environment and exert pollution load in surrounding water bodies (Munnaf et al., 2014). It has been reported that industrial effluent has hazardous effect on water quality, habitat and complex effects 
on flowing waters (Ethan et al., 2003). Industrial wastes and effluents contain toxic and hazardous substances which are detrimental to human health and are considered as threats to the existence of human being (Islam et al., 2012, Jimena et al., 2008, Rajaram and Das, 2008 and Ogunfowokan et al., 2005).
Industrial effluents are a main source of direct and often continuous input of pollutants into aquatic ecosystems with long-term implications on ecosystem functioning (Lah et al., 2004; Smolders et al., 2004; Chan et al., 2003; Odeigah and Osanyipeju, 1995). The effluents also include detergents those

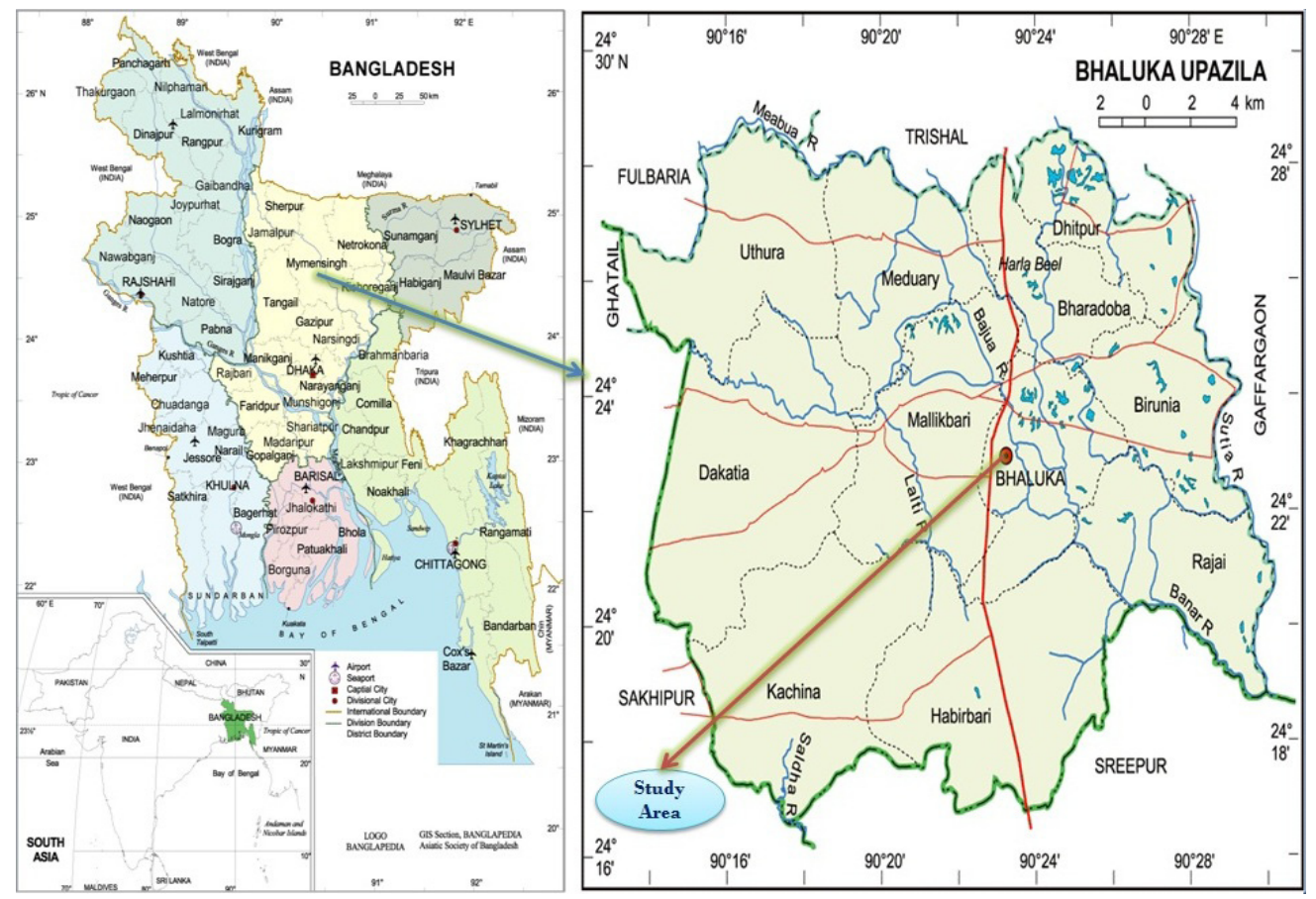

Fig. 1: Map showing the study area of Bhaluka upazila (Modified from Banglapedia, 2009)

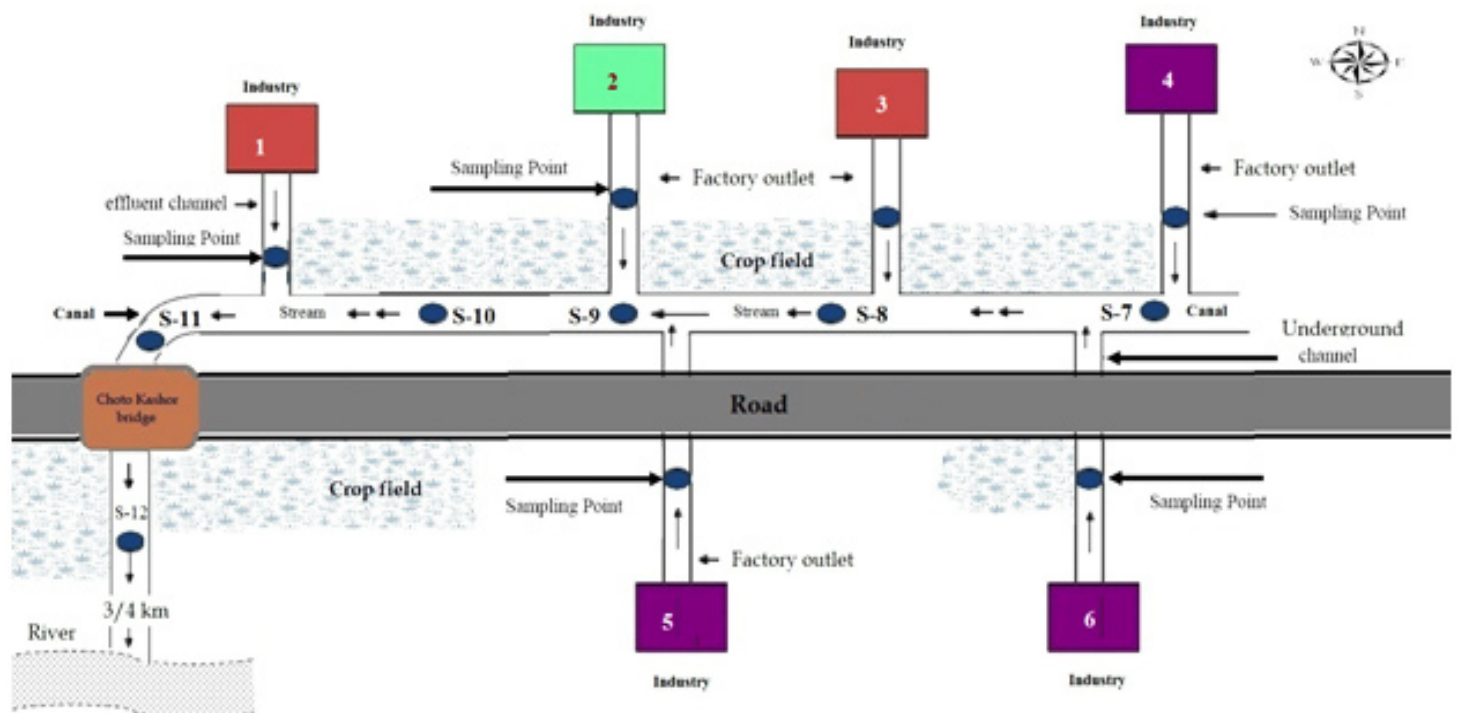

Fig. 2: Schematic representation of the selected sampling sites 
create a mass of white foam in the surface waters. The World Bank have identified 72 toxic chemicals in our water solely from textile dyeing, 30 of which are cannot be removed (Munnaf et al., 2014). All these chemicals are quite harmful or even fatally toxic to fish (Kumar, 1996) and other aquatic populations (Chakravarty et al., 1959). In Bangladesh unplanned industrialization along with insufficient use of ETP and direct discharge of wastewater into nearby water bodies make the surface water more polluted (Sultana et al., 2009) and create harmful effects on public health, livestock, aquatic life and wildlife (Ugochukwu and Leton, 2004; Haque et al., 2002).

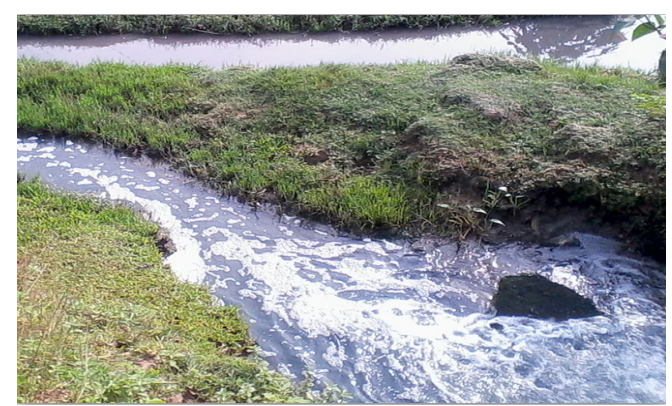

Fig. 3: A sampling sight of a textile industry outlet
It is well established that pollution lowers the quality of life in various aspects and affects health and life span (Grover and Kaur, 1999). Water pollution caused by industrial effluent discharges has become a worrisome phenomenon due to its impact on environmental health and safety (Sarker et al., 2015; Sarker, 2013; Lokhande, 2011). Due to proliferation of textile, pharmaceutical and other industries in Bhaluka Upazila, a large amount of industrial chemicals and wastes are generated every day which are dumped into the adjacent water bodies. As industrialization and urbanization of Bhaluka are surging at faster rate than other areas of Mymensingh district, it becomes important to be aware of water quality as it affects overall environment. Therefore, this study was undertaken to evaluate significant environmental parameters of effluents of Bhaluka industrial area.

\section{MATERIALS AND METHODS}

\section{Study area}

The study area (Fig. 1) was located in Habirbari union of Bhaluka upazila (latitude 24.3750N $\mathrm{N}$ and longitude $90.3778^{\circ} \mathrm{E}$ ) (Banglapedia, 2009). Study involved sampling of effluents from

Table 1: Physicochemical characterization of effluent samples

\begin{tabular}{lccccccc}
\hline $\begin{array}{l}\text { S. } \\
\text { No. }\end{array}$ & $\begin{array}{c}\text { Temp. } \\
\left({ }^{\circ} \mathbf{C}\right)\end{array}$ & Color & Odor & $\mathbf{p H}$ & $\begin{array}{c}\text { TDS } \\
\mathbf{m g} / \mathbf{L}\end{array}$ & $\begin{array}{c}\text { EC } \\
\boldsymbol{\mu S} / \mathbf{c m}\end{array}$ & $\begin{array}{c}\text { DO } \\
\mathbf{m g} / \mathbf{L}\end{array}$ \\
\hline 1 & 30.2 & Brown & Fishy & 7.95 & 162.8 & 269.70 & 0.32 \\
2 & 29.8 & Light Brown & Foul & 8.75 & 86.48 & 160.89 & 0.50 \\
3 & 29.2 & Light Brown & Pungent & 8.85 & 53.68 & 94.870 & 0.49 \\
4 & 29.1 & Brown & Fishy & 9.80 & 89.67 & 176.97 & 0.51 \\
5 & 27.2 & Grey & Pungent & 7.50 & 267.05 & 357.54 & 0.69 \\
6 & 29.3 & Clear & Foul & 8.72 & 156.05 & 365.58 & 0.30 \\
7 & 26.8 & Mauve & Pungent & 7.69 & 213.46 & 315.63 & 0.76 \\
8 & 28.7 & Dark mauve & Fishy & 8.34 & 158.07 & 266.00 & 0.37 \\
9 & 28.3 & Mauve & Pungent & 9.00 & 204.76 & 328.00 & 0.64 \\
10 & 28.9 & Light Mauve & Pungent & 8.85 & 200.34 & 312.54 & 0.50 \\
11 & 27.5 & Dark brown & Pungent & 9.05 & 169.98 & 258.78 & 0.90 \\
12 & 26.9 & Black & Fishy & 8.66 & 119.06 & 250.48 & 1.30 \\
Max. & 30.2 & - & - & 9.80 & 267.05 & 365.58 & 1.30 \\
Min. & 26.8 & - & - & 7.50 & 53.68 & 94.870 & 0.30 \\
Mean & 28.49167 & - & - & 8.59 & 156.78 & 263.08 & 0.606 \\
SD & 1.146107 & - & - & 0.63 & 61.26 & 82.700 & 0.282 \\
\hline
\end{tabular}


outlets of 6 industries (Table 1) and at 6 selected points along the receiving streams (Fig. 2).

\section{Sampling}

The waste water samples were collected during September 2013 from 12 stations of surrounding industrial aquatic environment (directly from the outlet of the factory linked to the canal). Twelve samples were collected for physico-chemical analysis at a distance of about 50 meters from each other. The samples were collected using $100 \mathrm{ml}$ sampling bottles clamped to the pole from estimated centre of the main flow considering full height of water column (about $5 \mathrm{~cm}$ ). Sampling points were designed in relation to industries as depicted by Fig. 2 .

\section{Analytical procedures}

Analysis of different parameters was done at the central laboratory of Bangladesh Agricultural University and soil science laboratory of Bangladesh Institute of Nuclear Agriculture, Mymensingh, Bangladesh. Water color was observed by naked eyes and odor was felt by nose during collection. The $\mathrm{pH}$ value of water samples was measured by pH meter (WTW pH 522, Germany) as mentioned by Singh and Parwana (1999). Temperature was noted at the site of sampling using portable calibrated mercury thermometer (EPA, 1999 and 1998). EC and TDS were determined by conductivity meter following the procedure of Richard (1954). DO of the samples was measured with the help of DO meter (YSI, Model 58, USA).

In case of ionic constituents, calcium was determined by EDTA titrimetric method using $\mathrm{Na}_{2}$ EDTA as a chelating agent (Singh and Parwana, 1999; Page et al., 1982). Phosphorus content was determined colorimetrically by stannous chloride $\left(\mathrm{SnCl}_{2}\right)$ method according to the procedure outlined by APHA (1995). Flame emission spectrophotometer (Jenway PEP7, UK) was used to determine potassium and sodium contents of the samples.

\section{Data Analysis}

The SPSS and Microsoft Office Excel software were used for data analysis. Various descriptive statistical measures were used for categorization and describing the variables.

\section{RESULTS AND DISCUSSION}

\section{Industrial effluent analysis}

The $\mathrm{pH}$ values (Table 1) ranged from 7.5 to 9.8 with a mean value of 8.59 , indicating alkalinity of the effluents. The $\mathrm{pH}$ of some samples fluctuated

Table 2: Concentration of $\mathrm{Ca}+, \mathrm{Na}+, \mathrm{K}+$ and $\mathrm{PO} 43-$ $(\mathrm{mg} / \mathrm{L})$ in effluents

\begin{tabular}{lcccc}
\hline Sample ID & $\mathbf{C a}^{2+}$ & $\mathbf{N a}^{+}$ & $\mathbf{K}^{+}$ & $\mathbf{P O}_{4}{ }^{3-}$ \\
\hline 1 & Trace & 57.35 & 26.30 & 9.58 \\
2 & 2.07 & 51.97 & 24.20 & 8.49 \\
3 & 2.80 & 62.71 & 22.80 & 3.41 \\
4 & Trace & 57.23 & 17.30 & 10.67 \\
5 & 0.39 & 36.58 & 6.40 & 1.89 \\
6 & 8.08 & 67.46 & 8.90 & 3.34 \\
7 & 4.14 & 75.33 & 23.04 & 3.97 \\
8 & 2.06 & 75.17 & 14.60 & 3.05 \\
9 & 5.12 & 83.77 & 11.50 & 3.63 \\
10 & Trace & 62.36 & 26.28 & 2.68 \\
11 & 0.24 & 82.01 & 23.04 & 4.75 \\
12 & Trace & 79.14 & 23.44 & 3.18 \\
Max. & 8.08 & 83.77 & 26.30 & 10.67 \\
Min. & Trace & 36.58 & 6.40 & 1.89 \\
Mean & 2.075 & 65.92 & 18.98 & 4.88 \\
SD & 2.5858 & 14.0004 & 7.0025 & 2.9481 \\
\hline
\end{tabular}


from average value because these industries dealt with different processes using different chemicals which might be responsible for this fluctuation. The observed $\mathrm{pH}$ value of the samples exceeded the range of fish culture standard (Meade, 1998), reflecting its unsuitability for aquatic life and for all types of water use. According to Ayers and Westcot (1985), most of the samples were problematic for long-term irrigation where the acceptable value for irrigation ranged from 6.5 to 8.4. Wastewater temperature $\left(26.8-30.2^{\circ} \mathrm{C}\right)$ revealed that it was moderately standard; thereby indicating values within the permissible limits of dumping. Colors of the samples were mauve, dark mauve, grey, brown, dark brown or black (Fig. 3 and Table 1).

Therefore, the wastewater was unsuitable not only for aquaculture but also for agriculture. Unpleasant odor generated from effluents indicated that the water was unsuitable for aquatic ecosystem and human health.

Electrical conductivity (EC) of collected water samples (Table 1) were within the range of 94.87 to $365.58 \mu \mathrm{S} \mathrm{cm}^{-1}$ with an average of 263.082 $\mu \mathrm{S} \mathrm{cm}^{-1}$ indicating low salinity. TDS concentration of the sampling points ranged from 53.68 to 267.05 $\mathrm{mg} / \mathrm{L}$ with the mean value of $156.78 \mathrm{mg} / \mathrm{L}$ (Table 1 ). All of the analyzed samples (1-12) possessed lower TDS concentration than the standard value (500 mg/L). The degree of relationship between EC and TDS of the water samples showed that TDS concentration was increasing proportionally with EC value (Fig. 4). The value of EC and TDS had a significant positive relationship at $1 \%$ level of significance. As total concentration of dissolved solids in water is a general indication of its suitability for irrigation and aquaculture purpose, observed results indicated suitability of this water for irrigation

Table 3: Pearson correlation coefficients matrix of metal ion concentrations $(n=12)$

\begin{tabular}{lcccc}
\hline Parameters & $\mathbf{C a}^{2+}$ & $\mathbf{N a}^{+}$ & $\mathbf{K}^{+}$ & $\mathbf{P O}_{4}{ }^{3-}$ \\
\hline $\mathrm{Ca}^{2+}$ & 1 & & & \\
$\mathrm{Na}^{+}$ & 0.292 & 1 & & \\
$\mathrm{~K}^{+}$ & -0.474 & 0.170 & 1 & \\
$\mathrm{PO}_{4}{ }^{3-}$ & -0.290 & -0.254 & 0.355 & 1 \\
\hline
\end{tabular}

(Ayers and Westcot, 1976) and aquaculture (Meade, 1998) on the basis of TDS concentration alone.

DO of collected effluent samples were within the range of 0.3 to $1.3 \mathrm{mg} / \mathrm{L}$ with an average of $0.60 \mathrm{mg} / \mathrm{L}$ (Table 1). DO content of the samples was much lower than the standard (ADB, 1994). This lower value of DO was because water used in these industries underwent different processes in high temperature. Temperature decreases DO of water (MiCorps, 2014; MPCA, 2009). High correlations between water parameters reflect the fact that these parameters had similar pollution source (Armah et al., 2010). Significant negative correlation existed between available $\mathrm{pH}$ and TDS at $5 \%$ level of significance (Fig. 5).

Concentration of DO and temperature had a significant negative relationship at $1 \%$ level of significance (Fig. 6). Correlation between $\mathrm{pH}$ and temperature shows significant positive relationship which means mutual increase of the values (Fig. 7).

\section{Ionic constituents}

Phosphate content of the samples varied from 1.89 to $10.67 \mathrm{mg} / \mathrm{L}$. Among all, most of the samples (91.66\%) exceeded permissible limit of irrigation water (Ayers and Westcot, 1985) which proves unsuitability of the effluents for irrigation.

Calcium content in effluent samples varied from 0 to $8.08 \mathrm{mg} / \mathrm{L}$ with an average value of 2.075 $\mathrm{mg} / \mathrm{L}$ (Table 2). Irrigation water containing less than $20 \mathrm{me} / \mathrm{L}(800 \mathrm{mg} / \mathrm{L})$ of $\mathrm{Ca}$ is suitable for irrigating crops (Ayers and Westcot, 1985). On the basis of Calcium content, all effluent samples could safely be used for irrigation without affecting soil.

Study result revealed that concentration of available $\mathrm{Na}^{+}, \mathrm{Ca}^{2+} ; \mathrm{K}^{+}, \mathrm{Na}^{+}$and $\mathrm{PO}_{4}{ }^{3-}, \mathrm{K}^{+}$in the samples had a significant positive relationship. On the contrary, concentration of available $\mathrm{Ca}$ and $\mathrm{PO}_{4}$ showed a significant negative relationship (Table 3).

Concentration of $\mathrm{Na}$ varied from 36.58 to $83.77 \mathrm{mg} / \mathrm{L}$ with the mean value of 65.92 (Table 2). According to Ayers and Westcot (1985), measured $\mathrm{Na}$ content in all of the effluent samples were far 


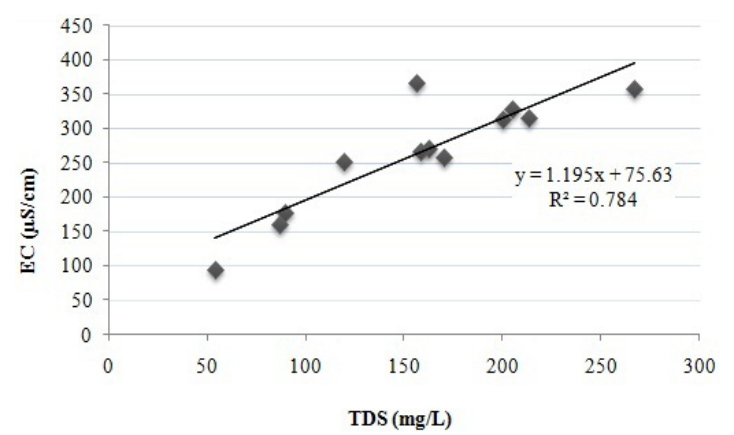

Fig. 4: Correlation between EC and TDS

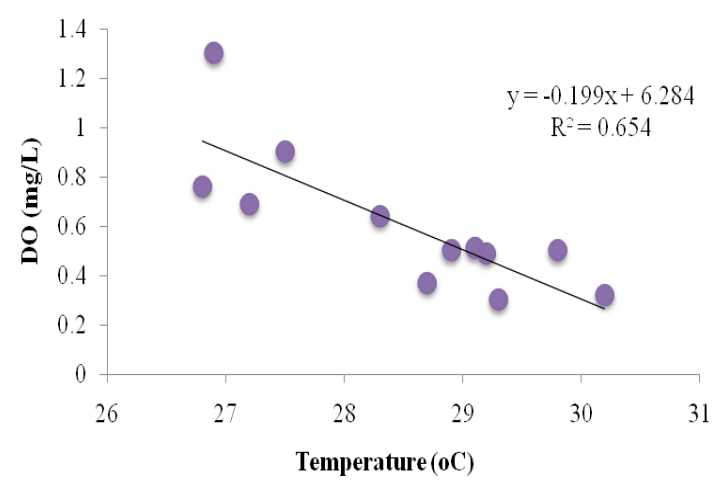

Fig. 6: Correlation between DO and temperature

below the specified limit. In respect of Na content, all samples could be safely applied for long-term irrigation without any harmful effect.

On the other hand, $\mathrm{K}$ concentration in the samples varied from 6.4 to $26.3 \mathrm{mg} / \mathrm{L}$ with the mean value of $18.98 \mathrm{mg} / \mathrm{L}$ (Table 2). Among 12 wastewater samples, the ratios of mean concentrations to background values were ranked in the order: $\mathrm{Na}^{+}>$ $\mathrm{K}^{+}>\mathrm{Ca}^{2+}$ (Table 2).

\section{CONCLUSION}

The analysis showed that all effluents contained acceptable temperature and concentration of $\mathrm{EC}, \mathrm{Ca}, \mathrm{Na}, \mathrm{K}$, whereas due to presence of one

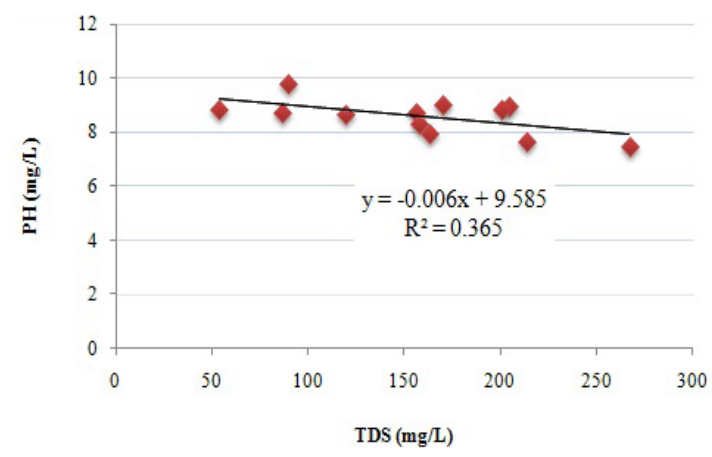

Fig. 5: Correlation between pH and TDS

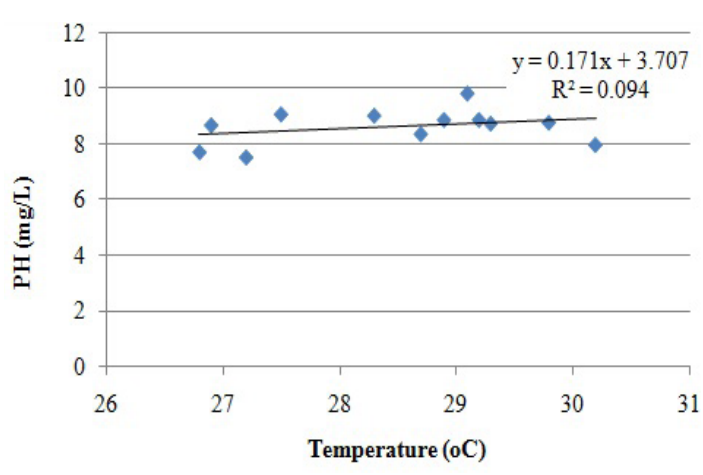

Fig. 7: Correlation between PH and temperature

or several incongruities among tested parameters viz. $\mathrm{pH}$, color, odor, TDS, $\mathrm{DO}, \mathrm{PO}_{4}$, were proven unsuitable for aquaculture and irrigation. Therefore, considering all of these facts, wastewater samples of the present study could not be utilized for irrigation and aquaculture purposes because several properties were proven unsuitable for plants and aquatic lives.

\section{ACKNOWLEDGEMENT}

The authors are thankful to scientists of soil science division, Bangladesh Institute of Nuclear Agriculture (BINA), Mymensingh, Bangladesh, for providing us with laboratory facilities for chemical analyses. 


\section{REFERENCES}

1. ADB (Asian Development Bank), Training Manual for Environmental Monitoring, Engineering Science Inc., USA, 1994, 2-16

2. APHA (American Public Health Association), Standard Methods for the Examination of Water and Wastewater, 19 $9^{\text {th }}$ edition. Washington: American Public Health Association, 1995

3. Armah, F. A.; Obiri, S.; Yawson, D. O.; Onumah, E. E.; Yengoh, G. T.; Afrifa, E. K.; Odoi, J. O., Journal of Environmental Science and Health Part A, 2010, 45(13), 1804-1813

4. Ayers, R.S.; Westcot, D.W., Water Quality for Agriculture. FAO irrigation and drainage paper, 1976, 29(1), 4096

5. Ayers, R.S.; Westcot, D.W. Water Quality for Agriculture. FAO irrigation and drainage paper, 1985, 29

6. Banglapedia, National Encyclopedia of Bangladesh, Asiatic Society of Bangladesh, 2009

7. Chakrabarty, R. D.; Roy, P.; Singh, S. B., Indian Journal of Fisheries, 1959, 6(1), 186-203

8. Chan, Y.K.; Wong, C.K.; Hsieh, D.P.H.; Lau, T.K.; Wong, P.K., Environmental Toxicology, 2003, 18(5), 312- 316

9. EPA (Environmental Protection Agency), Methods for chemical analysis of industrial effluents, USA, 1998

10. EPA (Environmental Protection Agency), Wastewater Treatment Manuals: Treatment Systems for Small Communities, Business, Leisure Centers and Hotels, Ireland, 1999

11. Gana, J. M.; Ordóñez, R.; Zampini, C.; Hidalgo, M.; Meoni, S.; Isla, M. I., Journal of Hazardous Materials, 2008, 155(3), 403406

12. Grover, I. S.; Kaur, S., Mutation Research/ Fundamental and Molecular Mechanisms of Mutagenesis, 1999, 426(2), 183-188

13. Haque, S.; Yasmin, H.; Rahman, M. H., Environmental pollution in Bangladesh, Earth Community Organization (ECO), 2002, 3847

14. Islam, M. S.; Chowdhury, M. A. H.; Billah, M. M. S.; Tusher, T. R.; Sultana, N., Bangladesh Journal of Environmental Science, 2012, 23, 123-130
15. Kumar, A., Pol. Arch. Hydrobiol., 1996, 18(4), 469-476

16. Lah, B.; Gorjanc, G.; Nekrep, F. V.; MarinsekLogar, R., Bulletin of environmental contamination and toxicology, 2004, 72(3), 607-616

17. Meade, J. W., Aquaculture management, India: CBS Publishers and Distributors, 1998, 9

18. Munnaf, A.; Islam, M. S.; Tusher, T. R.; Kabir, M. H.; Molla, M. A. H., Journal of Environmental Science and Natural Resources, 2014, 7(1), 257-263

19. Lokhande, R. S.; Singare, P. U.; Pimple, D. S., International Journal of Ecosystem, 2011, 1(1), 1-9 [doi:10.5923/j.ije.20110101.01]

20. MiCorps (The Michigan Clean Water Corps), Dissolved Oxygen and Temperature, Michigan Department of Environmental Quality, USA, (2014) [http://goo.gl/kFMlpJ on 14.02.2015]

21. MPCA (Minnesota Pollution Control Agency), Low Dissolved Oxygen in Water Causes, Impact on Aquatic Life: An Overview, 2009

22. Nedeau, E. J.; Merritt, R. W.; Kaufman, M. G., Environmental Pollution, 2003, 123(1), 1-13

23. Odeigah, C.; Osanyinpeju, O., Food and Chemical Toxicology, 1995, 33, 501-505

24. Ogunfowokan, A. O.; Okoh, E. K.; Adenuga, A. A.; Asubiojo, O. I., Journal of applied sciences, 2005, 5(1), 36-43

25. Page, A. L.; Miller, R. H.; Keeney, D. R., Methods of Soil Analysis. Part-2, 2nd edition, American Society of Agrononomy, Wisconsin, USA, 1982, 98-765

26. Rajaram, T.; Das, A., Futures, 2008, 40(1), 56-69

27. Richard, L. A., Diagnoses and improvement of saline and alkali soils. Agriculture Hand Book, USA, 1954

28. Sarker, B. C.; Baten, M. A.; Ekram-ul Haque, M.; Das, A. K.; Hossain, A.; Hasan, M. Z., Current World Environment, 2015, 10(1), 61-66 [doi: http://dx.doi.org/10.12944/ CWE.10.1.07]

29. Sarker, B.C. Assessment of Industrial Effluents Quality: A Case Study of Bhaluka Industrial Area, Mymensingh, Bangladesh, MS Thesis, 2013 [DOI: 10.13140/2.1.1914.6565] 
30. Singh, K. P.; Parwana, H. K., Indian Journal of Environmental Protection, 1999, 19, 241244

31. Smolders, R.; Bervoets, L.; Blust, R., Environmental Pollution. 2004, 132(2), 231243
32. Sultana, M. S.; Islam, M. S.; Saha, R.; Al-Mansur, M. A., Bangladesh Journal of Scientific and Industrial Research, 2009, 44(1), 65-80

33. Ugochukwu, C. N. C.; Leton, T. G., African Journal of Environmental Assessment and Management. 2004, 8, 27-30 